\title{
On the spiders (Arachnida: Aranei) from Armenia
}

\section{O пауках (Arachnida: Aranei) Армении}

\author{
K.G. Mikhailov ${ }^{1}$, E.A. Propistsova ${ }^{2}$ \\ К.Г. Михайлов ${ }^{1}$, Е.А. Прописцова ${ }^{2}$
}

\footnotetext{
1 Zoological Museum, Moscow Lomonosov State University, Bolshaya Nikitskaya Str. 2, Moscow 125009 Russia. E-mail: mikhailov2000@gmail.com

1 Зоологический музей МГУ им. М.В. Ломоносова, ул. Большая Никитская, 2, Москва 125009 Россия.

${ }^{2}$ Department of Entomology, Biological Faculty, Moscow Lomonosov State University, Leninskie Gory, Moscow 119234 Russia. E-mail: evgenya.jeny@yandex.ru

${ }^{2}$ Кафедра энтомологии, Биологический факультет МГУ им. М.В. Ломоносова, Ленинские горы, Москва 119234 Россия.
}

KEY WORDS: Araneae, Caucasus, Armenia, faunistics.

КЛЮЧЕВЫЕ СЛОВА: Araneae, Кавказ, Армения, фаунистика.

ABSTRACT. During a short research trip to Armenia in May 2015, 19 spider species were collected. Of them, 15 are new to the fauna of Armenia.

How to cite this article: Mikhailov K.G., Propistsova E.A. 2017. On the spiders (Arachnida: Aranei) from Armenia // Arthropoda Selecta. Vol.26. No.4. P.369371. doi: 10.15298/arthsel.26.4.11

РЕЗЮМЕ. По результатам краткой поездки в Армению в мае 2015 г. собрано 19 видов пауков, 15 из которых — новые для фауны Армении.

\section{Introduction}

At present, the spider fauna of the Caucasus totals 1105 species [Otto, 2017]. In comparison with Azerbaijan, Georgia and the Russian northern Caucasus, the fauna of Armenia is poorly-studied [Mikhailov, 2013, 2016]. The latest checklist [Mikhailov, 2016] contains only 162 species, whereas 619 and 716 spider species are presently recorded from Georgia and Azerbaijan, respectively [Otto, 2017]. The areas of all three Transcaucasian republics being 86.6 (Azerbaijan), 69.7 (Georgia), and 29.8 (Armenia) sq.km x 10 $0^{3}$, this in no way corresponds to their known spider diversity. No detailed catalogue of Armenian spiders has hitherto been compiled.

The objective of the present note is to provide new data on the spiders of Armenia. The underlying material is kept in the Zoological Museum, Moscow Lomonosov State University (ZMMU, Moscow, Russia).

\section{Material and methods}

This study is based on the material collected in Armenia in May 2015 by E.A. Propistsova and identified by K.G. Mikhailov and E.A. Propistsova.

A list of localities (see also Map):

Akhtala, $41^{\circ} 09^{\prime} 21.9^{\prime \prime} \mathrm{N}, 44^{\circ} 45^{\prime} 86.2^{\prime \prime} \mathrm{E}, 736 \mathrm{~m}, 4.05$. 2015
Haghpat, $41^{\circ} 05^{\prime} 48^{\prime \prime} \mathrm{N}, 44^{\circ} 42^{\prime} 57.4^{\prime \prime} \mathrm{E}, 1000$ m, 4.05. 2015;

Hankavan, $40^{\circ} 38^{\prime} 18.7^{\prime \prime} \mathrm{N}, 4^{\circ} 30^{\prime} 06.9^{\prime \prime} \mathrm{E}$, ca. 2000 $\mathrm{m}, 2.05 .2015$;

Tatev, $39^{\circ} 23^{\prime} 66.7^{\prime \prime} \mathrm{N}, 46^{\circ} 15^{\prime} 30.3^{\prime \prime} \mathrm{E}, 1150 \mathrm{~m}, 7.05$. 2015;

Haghartsin Monastery, 40 48 $12.7^{\prime \prime} \mathrm{N}, 44^{\circ} 53^{\prime}$ 45.1"E, $1450 \mathrm{~m}, 3.05 .2015$;

Garni Gorge, $40^{\circ} 06^{\prime} 35.9^{\prime \prime} \mathrm{N}, 44^{\circ} 43^{\prime} 50.1^{\prime \prime} \mathrm{E}, 1429$ m, 8.05.2015;

Dilijan National Park, Lake Parzlich shore, $40^{\circ} 45^{\prime}$ 18. $7^{\prime \prime N}$, 445' $70.3^{\prime \prime} \mathrm{E}, 1330 \mathrm{~m}, 3.05 .2015$.

Taxonomy is given following WSC [2017].

\section{Results}

A total of 19 spider species from 9 families have been identified, including one, Pellenes arciger (Walckenaer, 1837), new to the Caucasus and 15 reported from Armenia for the first time. In addition, the genera Nematogmus Simon, 1884, Trematocephalus F. Dahl, 1886 (both in Linyphiidae), Pellenes Simon, 1876 (Salticidae), Pisaura Simon, 1885 (Pisauridae), and the family Pisauridae are new to the fauna of Armenia.

Family Araneidae

Mangora acalypha (Walckenaer, 1802)

Material examined: $10^{7}, 3$ juv., Akhtala; 1 juv., Haghpat.

DISTRIBUTION. A trans-Palaearctic pattern ranging from North Africa to China: Xinjiang. Caucasus: the Russian northern Caucasus, Georgia, Azerbaijan, Armenia.

Family Clubionidae

Clubiona lutescens Westring, 1851

Material examined: $1 \bigcirc^{7}$, Hankavan.

DISTRIBUTION. A trans-Palaearctic pattern ranging from Europe to Japan. Introduced to North America. Caucasus: the Russian northern Caucasus, Georgia, Azerbaijan, Armenia. 


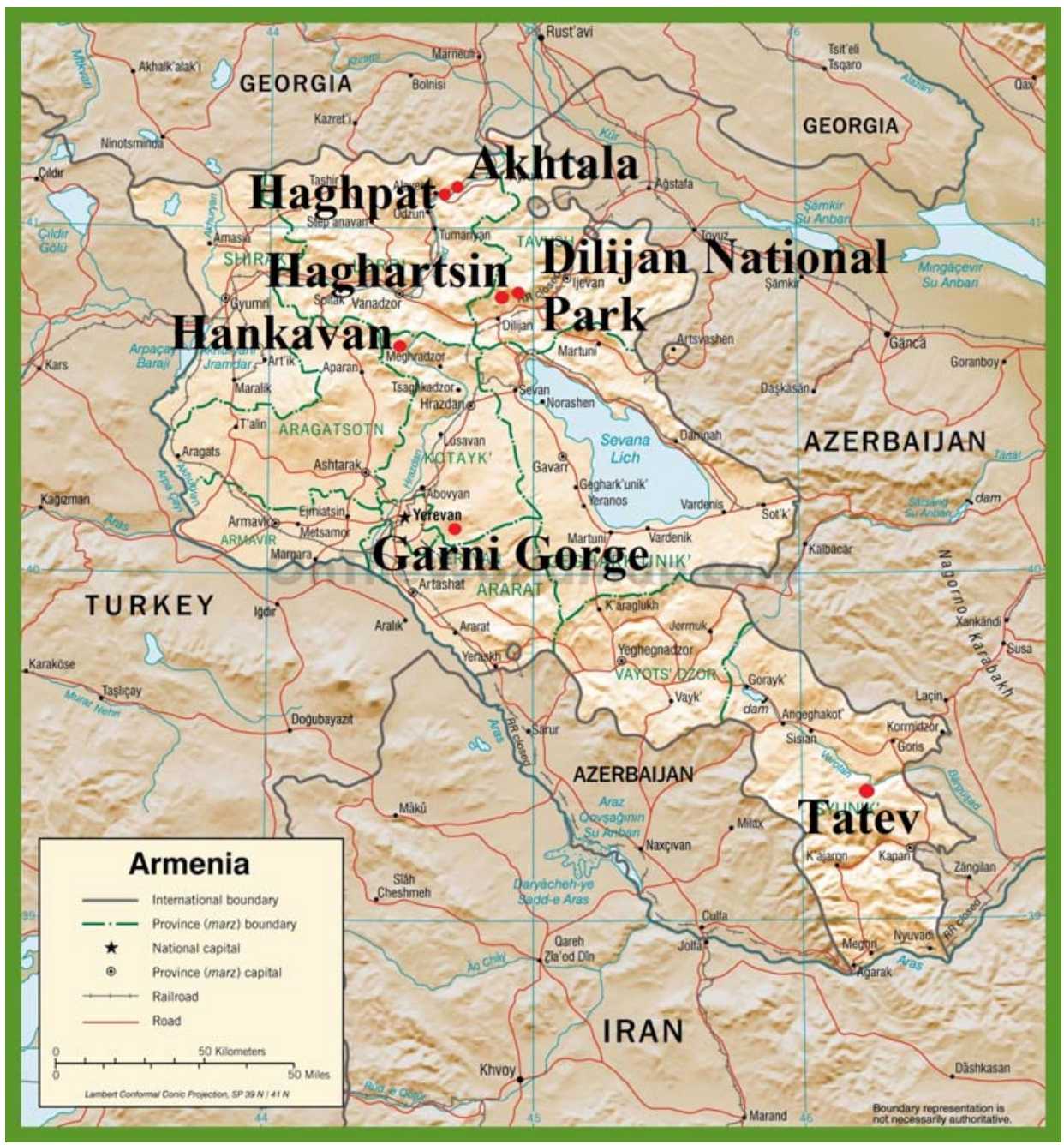

Map 1. Collecting localities in Armenia.

Карта 1. Места сбора в Армении.

Family Gnaphosidae

Nomisia conigera (Spassky, 1941)

Material examined: $1 \mathrm{O}^{\text {T}}$, Tatev.

DISTRIBUTION. A West Palaearctic nemoral pattern ranging from Turkey to Middle Asia (Kyrgyzstan and Tadjikistan being the easternmost regions). Caucasus: Georgia, Azerbaijan. New to Armenia.

\section{Zelotes longipes (L. Koch, 1866)}

Material examined: 1 , Haghartsin Monastery.

DISTRIBUTION. A West Palaearctic pattern ranging from Europe to China: Xinjiang. Caucasus: the Russian northern Caucasus, Georgia, Azerbaijan. New to Armenia.

Family Linyphiidae

Araeoncus caucasicus Tanasevitch, 1987

Material examined: $10^{7}$, Garni Gorge.

DISTRIBUTION. Crimea, Caucasus, Iran, Middle Asia. Caucasus: the Russian northern Caucasus, Georgia, Azerbaijan. New to Armenia.
Nematogmus sanguinolentus (Walckenaer, 1841)

Material examined: $1 \sigma^{7}$, Akhtala.

DISTRIBUTION. A trans-Palaearctic pattern ranging from North Africa to the Far East (Japan, Korea, China). Caucasus: the Russian northern Caucasus, Georgia. New to Armenia.

Trematocephalus cristatus (Wider, 1834)

Material examined: $10^{7}$, Dilijan National Park.

DISTRIBUTION. A trans-Palaearctic pattern ranging from Europe to the Russian Far East and China. Caucasus: the Russian northern Caucasus, Georgia, Azerbaijan. New to Armenia.

Family Lycosidae

Alopecosa farinosa (Herman, 1879)

$=$ A. accentuata (auct. non Latreille, 1817)

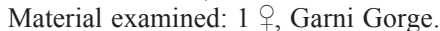

DISTRIBUTION. A trans-Palaearctic pattern. Caucasus: the Russian northern Caucasus, Georgia, Azerbaijan. New to Armenia. 
Pardosa caucasica Ovtsharenko, 1979

Material examined: $2 \sigma^{7} \sigma^{7}, 1$, Haghartsin Monastery; $3 \sigma^{7} \sigma^{7}$, Dilijan National Park.

DISTRIBUTION. Crimea, Caucasus: the Russian northern Caucasus, Georgia, Azerbaijan. New to Armenia.

Pardosa hortensis (Thorell, 1872)

Material examined: 1 , Dilijan National Park.

DISTRIBUTION. Most probably a West Palaearctic pattern. Caucasus: the Russian northern Caucasus, Georgia, Azerbaijan. New to Armenia.

Family Pisauridae

Pisaura novicia (L. Koch, 1878)

Material examined: $1 \sigma^{7}, 1$ o, Haghartsin Monastery; $1 \sigma^{7}$, Dilijan National Park.

DISTRIBUTION. Southern Europe and Turkey to Middle Asia. Caucasus: the Russian northern Caucasus, Georgia. New to Armenia.

Family Salticidae

Evarcha arcuata (Clerck, 1758)

Material examined: $1 O^{7}$, Haghartsin Monastery.

DISTRIBUTION. A trans-Palaearctic pattern ranging from Europe to the northern Far East and Japan. Caucasus: the Russian northern Caucasus, Georgia, Azerbaijan, Armenia.

Heliophanus dunini Rakov et Logunov, 1997

Material examined: $3 \sigma^{2} O^{2}$, Dilijan National Park.

DISTRIBUTION. A West Palaearctic pattern ranging from Turkey to Kazakhstan. Caucasus: the Russian northern Caucasus, Azerbaijan. New to Armenia.

Pellenes arciger (Walckenaer, 1837)

Material examined: $1 \sigma^{\top}$, Garni Gorge.

DISTRIBUTION. Southern Europe. New to the Caucasus and Armenia (Crimea being the nearest record).

Philaeus chrysops (Poda, 1761) Gorge.

Material examined: $1 \bigcirc^{\top}, 2$ ㅇ, 1 juv., Tatev; 1 juv., Garn

DISTRIBUTION. A trans-Palaearctic pattern ranging from North Africa to the Far East (Russia, China, Korea). Caucasus: the Russian northern Caucasus, Georgia, Azerbaijan, Armenia.

\section{Family Tetragnathidae}

Metellina mengei (Blackwall, 1869)

Material examined: 1 , Dilijan National Park.

DISTRIBUTION. A Euro-Siberian pattern ranging from Europe to the Altai Mountains. Caucasus: the Russian northern Caucasus, Georgia. New to Armenia.

\section{Family Thomisidae}

Ozyptila praticola (C.L. Koch, 1837)

Material examined: $10^{\top}$, Garni Gorge.

DISTRIBUTION. A Holarctic pattern, missing from eastern Siberia. Caucasus: the Russian northern Caucasus, Georgia, Azerbaijan. New to Armenia.

Thomisus onustus Walckenaer, 1805

Material examined: 2 juv., Akhtala; 1 juv., Tatev; $10^{\top}, 3$ juv., Garni Gorge.

DISTRIBUTION. A trans-Palaearctic pattern ranging from Europe to the Far East (China, Korea). Caucasus: the Russian northern Caucasus, Georgia, Azerbaijan. New to Armenia.

Xysticus acerbus Thorell, 1872

Material examined: $10^{7}$, Garni Gorge.

DISTRIBUTION. Europe to Middle Asia and Mongolia. Caucasus: the Russian northern Caucasus, Georgia, Azerbaijan. New to Armenia.

Following a short, only 5-day long school zoological excursion, the spider list of Armenia is increased from 162 to 177 species belonging to 100 genera and 23 families. This is certainly far from being a complete number. We can expect the spider fauna of this region to comprise at least 400 species. Further studies are highly topical.

Acknowledgements. The work of the first author (KM) is supported by Moscow State University Project No. AAAA-A16-116021660077-3. Publication of this paper is supported by Russian Science Foundation project No. 14-50-00029. Mark Kalashian (Yerevan, Armenia) kindly provided us with a map of Armenia. The linguistic help of Sergei I. Golovatch (Moscow, Russia) is also deeply acknowledged. We are also grateful to Yuri M. Marusik (Magadan, Russia) and Stefan Otto (Leipzig, Germany) for the logistic help and criticism, as well as to the biological class of Moscow's High School \# 179 for arranging the trip to Armenia.

\section{References}

Mikhailov K.G. 2013. The spiders (Arachnida: Aranei) of Russia and adjacent countries: a non-annotated checklist // Arthropoda Selecta. Supplement No. 3. 262 p.

Mikhailov K.G. 2016. Advances in the study of the spider fauna (Aranei) of Russia and adjacent regions: a 2015 update // Vestnik zoologii. Vol.50. No.4. P.309-320. doi: 10.1515/vzoo2016-0038

Otto S. 2017. Caucasian spiders. A faunistic database on the spiders of the Caucasus. Version 08.2017. Available online http:/ /caucasus-spiders.info/ (accessed on October 26 ${ }^{\text {th }}, 2017$ )

World Spider Catalog (WSC). 2017. World Spider Catalog. Natural History Museum Bern, online at http://wsc.nmbe.ch, version 18.5 , accessed on October $26^{\text {th }}, 2017$

Responsible editor Yu.M. Marusik 